\title{
THE IBERO-BALEARIC REGION: ONE OF THE AREAS OF HIGHEST HYDROBIIDAE (GASTROPODA, PROSOBRANCHIA, RISSOOIDEA) DIVERSITY IN EUROPE
}

\author{
B. Arconada* and M. A. Ramos**
}

\begin{abstract}
The prosobranch mollusc family Hydrobiidae Troschel, 1857 has a cosmopolitan distribution and is made up of small to minute species that inhabit permanent aquatic ecosystems. It is one of the largest families within the superfamily Rissooidea. The evolutionary relationships between members of this family are still unclear due to: 1) insufficient available information regarding the morphological characters of many of the described taxa, 2) uncertainty concerning which morphological characters are of greatest taxonomic and phylogenetic interest, and 3) the rare use of molecular characters to study evolutionary relationships. In this work, we examine the reasons for the confusing systematics of hydrobiids. We include a diagnosis of the 13 genera and a list of the 43 species described and accepted to date for the Ibero-balearic region, along with data regarding their geographic distribution and a compilation of the most relevant bibliographical references. The Iberian Peninsula is one of the areas of greatest hydrobiid diversity in Europe, and has a large number of endemic genera and species in addition to those that have a typically circummediterranean distribution. Numerous hydrobiid species and populations are threatened, and in some cases, in danger of extinction due to the fragile nature of many of the ecosystems they inhabit.
\end{abstract}

Key words: Mollusca, Prosobranchia, Rissooidea, Hydrobiidae, systematics, biogeography, Iberian Peninsula, Spain, Europe.

\section{RESUMEN}

La región ibero-balear, una de las áreas de mayor diversidad de Hydrobiidae (Gastropoda, Prosobranchia, Rissooidea) en Europa

La familia Hydrobiidae Troschel, 1857 de moluscos prosobranquios, tiene distribución cosmopolita y está constituida por especies de tamaño pequeño (o incluso diminuto) que habitan ecosistemas acuáticos permanentes. Se trata de una de las familias con mayor número de especies de la superfamilia Rissooidea. Las relaciones evolutivas entre los miembros de esta familia son aún confusas debido a: (1) la insuficiente información disponible sobre los caracteres morfológicos de muchos de los táxones descritos, (2) la indefinición de los caracteres morfológicos de interés taxonómico y filogenético, y (3) la escasa aplicación de los caracteres moleculares para este fin. En este trabajo se revisa la confusa sistemática de los hidróbidos y sus causas. Además, se incluye una diagnosis de los 13 géneros y un listado de las 43 especies hasta ahora descritas y aceptadas en el ámbito ibero-balear, con datos sobre su distribución geográfica y la bibliografía más relevante. Se constata que la Península Ibérica constituye una de las áreas de mayor diversidad de hidróbidos en Europa, conteniendo un alto número de géneros y especies endémicos a los que se añaden otros de distribución circunmediterránea. La fragilidad de muchos de los ecosistemas en los que viven hace que muchas de sus especies y/o poblaciones se hallen amenazadas e incluso en peligro de extinción.

Palabras clave: Mollusca, Prosobranchia, Rissooidea, Hydrobiidae, sistemática, biogeografía, Península Ibérica, España, Europa.

* Museo Nacional de Ciencias Naturales (CSIC), Departamento de Biodiversidad y Biología Evolutiva. José Gutiérrez Abascal, 2. 28006 Madrid. España. (*) mona313@mncn.csic.es, (**) m.ramos@mncn.csic.es. 


\section{Introduction}

The family Hydrobiidae Troschel, 1857 (Class Gastropoda, Subclass Orthogastropoda, Superorder Caenogastropoda, Order Architaenioglossa, Superfamily Rissooidea) has a cosmopolitan distribution and comprises a numerous group of prosobranch gastropods. These molluscs are small to minute (generally less than $8 \mathrm{~mm}$ in height with many species' groups measuring less than $1 \mathrm{~mm}$ ) and have a markedly simple anatomical structure. Hydrobiidae s.s. originated in Laurasia, and according to the fossil record, dates back to around 280 MYA, a transition period between the Carboniferous and the Permian (Knight et al., 1960). This is one of the most numerous and taxonomically diverse mollusc families. According to the latest estimates, Hydrobiidae s.s. is made up of nearly 400 recent and fossil genera (Kabat \& Hersler, 1993), and has more than 1,000 described living species (Boss, 1971). With the exception of species of the type genus Hydrobia, which are marine or from brackish waters, practically all the rest live in freshwater environments. Others are stygobionts while a few are associated with brackish environments. At least one species, Fonscochlea zeidleri (Ponder et al., 1989), is amphibious and another is apparently terrestrial Falniowska neglectissima (Falnowski \& Steffeck, 1989). Some of the larger-sized species live in rivers (upper- or mid- river) and in lagoons. Due to their biomass and their role as primary consumers in the trophic chain, they are a major component of inland waters.

The higher systematics of the Hydrobiidae is confusing since the validity, taxonomic category, and phylogenetic relationships of the supra-specific taxa are still virtually unknown. In addition, the monophyly of the family is uncertain and the distinction between this family and other rissooidean families, such as Pomatiopsidae, is unclear (Davis et al., 1985). Problems defining the phylogenetic relationships at the suprafamilial level are fundamentally due to the scarce fossil record and the difficulties in studying this record. Problems also arise from the enormous diversity of hydrobiids, their broad geographic distribution, and the difficulties in identifying characters (and their states) that are of phylogenetic interest. In general, hydrobiids have unsculpted shells that offer few diagnostic characters. Furthermore, there is great intraspecific variability in most of the characters commonly used, which are also, in large part, homoplasic. Using anatomical characters is complicated by the molluscs' small size. Unlike larger prosobranchs, hydrobiid morphology is much simpler due to its miniaturization. Notwithstanding, it is generally accepted that the ancestors of Hydrobiidae s.s. were marine, a genus similar to extant species of Hydrobia, which had eurihaline capabilities and a broad geographic distribution (Hutchinson, 1993).

The aim of this paper is to review the systematics of the Hydrobiidae family, and to examine the distribution and conservation status of the described Ibero-balearic taxa both in this region and throughout the rest of Europe.

\section{Systematic position of Hydrobiidae}

Throughout its history, the Hydrobiidae family has been included in various superfamilies: Rissooidea (Thiele, 1929; Wenz, 1939; Taylor \& Sohl, 1962; Taylor, 1966; Davis, 1982; Bernasconi, 1992; Kabat \& Hershler, 1993; Wilke et al., 2001), Hydrobioidea (Radoman, 1973, 1983) and Truncatelloidea (Golikov \& Starobogatov, 1975; Ponder, 1988). It is currently ascribed to the first of these superfamilies, Rissooidea.

In the 19th century, Troschel (1857) defined Hydrobiidae as a group with "uncertain rank" belonging to Taenioglossata: Ctenobranchiata. Based on conchological, opercular, radular, pedal and penial features, other authors (Stimpson, 1865, Tryon, 1866,) have assigned the extant hydrobiids, together with other families, to a broad group of rissooidean snails. Beginning in the $20^{\text {th }}$ century, (Thiele, 1929; Wenz, 1939), there tends to be greater hierarchical structuring and more taxonomical categories are added. Thiele's classification is based primarily on conchological and radular characters; it includes 14 subfamilies within Hydrobiidae — seven of which are currently assigned to other groups of Rissooidea. This classification is later "broken up" (Morrison, 1949) and divided into 16 subfamilies (Morrison, 1971), based on the number of penial ducts, a character that rarely varies. Taylor (1966), studying a group of Mexican taxa, introduced new characters to the phylogenetic analysis (cephalic tentacles, corporal pigmentation, and reproduction), which were later questioned (Thompson, 1968).

After 1969, the systematic relationships of hydrobiids were studied more rigorously (Radoman, 1969). Grouping taxa at the supergenus level on the basis of conchological criteria was challenged. According to Radoman (1969), the phylogenetic analysis of this family should be more appropriately based on genital characters, primarily on the female genital system. Starobogatov (1970), followed by 
other authors (Golikov \& Starobogatov, 1975; Bernasconi, 1992), extensively used these criteria to review the Hydrobiidae, and to define genera within each family group. Hydrobiids are subsequently elevated to the superfamily level - Hydrobioidea(Nordsieck, 1972; Radoman, 1973, 1983; Giusti \& Pezzoli, 1982; Starobogatov \& Sitnikova, 1983) until Ponder and Waren (1988), re-assigned them to the Rissooidea - the classification they maintain to this day. Other authors combined some of the families within Hydrobiidae (Bodon \& Giusti, 1991, Kabat \& Hershler, 1993). Cladistic analyses performed with morphological characters generate inconsistent phylogenies (Falniowski \& Szarowska, 2000; Bodon et al., 2001) due to convergence and the scarcity of synapomorphies. Thanks to molecular phylogenies, the independent evolution of many of the usual morphological characters in classic hydrobiid systematics has recently been confirmed (Davis et al., 1998; Wilke \& Davis, 2000; Wilke et al., 2001).

Hershler and Ponder (1998) have written the most comprehensive, critical review of the mor-phological characters (and their states) that are of greatest phylogenetic interest. In these studies, they frequently continue to use terms such as "hydrobioid" that alludes to a standard morphotype of hydrobiid that shares a series of cephalic, pedal, opercular, genital, and pigmentary characters (Davis, 1979). Despite important advances made in the systematics of the group and the standardization of characters, the morphology (beyond shell and perhaps a few anatomical characters) of many nominal taxa is still unknown. In addition, there are extensive geographical regions that have yet to be explored. Therefore, the description and selection of characters, and character states of evolutionary interest should be considered preliminary at best, and any phylogenetic hypothesis for the group is merely tentative.

\section{Ibero-balearic hydrobiids}

Spain is one of the European countries with the largest number of known Hydrobiidae taxa. Nevertheless, there are comparatively few publi-shed works on the Ibero-balearic region. Besides Azpeitia's (1935) monograph on the genera Paludina and Amnicola, other works on a local scale worth mentioning are the conchological studies of Rosenhauer (1856), Fagot (1887, 1905, 1907), Bofill (1909), Bofill \& Haas (1920), Haas (1924, 1925, 1927), Gasull (1965, 1971, 1981), Altimira (1960), Schütt (1961), Boeters (1969) and Bech (1990). In 1988, Boeters published a revision of the
Hydrobiidae and Moitessieridae families on the Iberian Peninsula, dividing them into four subfamilies: Horatiinae, Hydrobiinae, Amnicolinae and Potamopyrginae. Other papers (Boeters \& Rolán, 1988; Rolán, 1991; Ramos et al., 2000; Arconada \& Ramos, 2001, 2002) published in the last decades about hydrobiids on the Iberian Peninsula described many new genera and species (e.g., Chondrobasis, Boetersiella, Spathogyna and Tarraconia). The most important changes have been noted among valvatiform hydrobiids (Arconada, 2000): where Boeters (1988) only recognised two genera (Horatia and Neohoratia) and nine species, there are currently nine genera and 19 species, some of which are still unpublished. In addition, it is doubtful that genus Neohoratia is represented in the Ibero-balearic fauna (Arconada \& Ramos, submitted).

According to classical classifications, 13 hydrobiid genera and a total of 43 species are recognized for the Iberian Peninsula and Balearic Islands. Following the most recent phylogenetic hypothesis (Wilke et al., 2001), the present review excludes those genera that have been placed into other families: Moitessieria and Bythiospeum (Moitessieriidae), Bithynia (Bithyniidae), Semisalsa (Cochliopidae) and Bythinella (Amnicolidae). The genus Potamopyrgus Stimpson, 1865 is also not discussed, since the only widely distributed species of this genus on the Iberian Peninsula is an invasive hydrobiid from New Zealand, Potamopyrgus antipodarum (Gray, 1843). Not yet described valvatiform hydrobiids have also been excluded from this work (Arconada, 2000). Besides a diagnosis of each genus (arranged in al-phabetical order), data are also provided on their geographic distribution within the Ibero-balearic region, and if applicable, within the world. The most relevant bibliographic references are also included.

\section{Alzoniella Giusti \& Bodon, 1984}

TYPE SPECIES: Alzoniella finalina Giusti \& Bodon, 1984.

TyPe LOCAlity: Spring in Ponci river, Liguria, Italy.

DiAGNOSIS: Shell ovate-conic; body generally unpigmented, lacking ocular spots; ctenidium with 5-11 lamellae; radula has a central tooth with 1-2 basal cusps on each side; female genitalia has a sacciform bursa copulatrix with a medium-size duct and two seminal receptacles; proximal seminal receptacle smaller than distal receptacle; penis with 1-2 glandular lobes, one of them is located in the base of the penis and the other one in a medial position on its inner edge. 
SPECIES AND IBERO-BALEARIC DISTRIBUTION: Alzoniella pyrenaica (Boeters, 1983) in Navarra and Basque Country.

WORLD Distribution: Czech Republic, Slovakia, Italy, Austria, France and Spain.

BibliOgRAPHY: Reischütz, 1983; Giusti \& Bodon, 1984; Bodon, 1988; Boeters, 1999, 2000, 2001; Bodon \& Cianfanelli, 2002.

\section{Belgrandia Bourguignat, 1869}

TYPE SPECIES: Cyclostoma gibbum Draparnaud, 1805

Type Locality: France, no specific locality

Diagnosis: Shell ovate-conic; ctenidium with 811 lamellae; radula has a central tooth with one basal cusp on each side; female genitalia has a sacciform and pedunculated bursa copulatrix and two seminal receptacles (proximal and distal) varying in size and shape; male genitalia has a penis with a distal end tapered and one or two lobes located in a medial position arising at the same level at inner and outer side of the penis; penis generally pigmented near the apex.

SPECIES AND IBERO-BALEARIC DISTRIBUTION: Belgrandia cf. marginata (Michaud, 1831), in Valencia, Cuenca, Alicante, Castellón, Tarragona and Barcelona; B. lusitanica (Paladilhe, 1867), in Beira Litoral; B. heussi (Boettger, 1963), in Ribatejo.

World DisTRIBUTION: Croatia, Germany, France, Italy, United Kingdom, Portugal, Spain and Morocco.

BibliogRAPHY: Kristensen, 1985; Boeters, 1988; Rolán, 1990; Haase, 2000; Falkner et al., 2002.

\section{Belgrandiella Wagner, 1927}

TYPE SPECIES: Belgrandia kusceri Wagner, 1914

TYPE LOCALITY: Rakek, Slovenia.

DiAGNOSIS: Minute shell ovate-conic; ctenidium with 3-10 lamellae; radula has a central tooth with 1-2 basal cusps on each side; female genitalia has a bursa copulatrix with a long duct and a proximal and pedunculated seminal receptacle; penis with a non-glandular lobe located in a medial position on its inner edge.

SPECIES AND IBERO-BALEARIC DISTRIBUTION: Belgrandiella elliptica (Paladilhe, 1874) in Navarra and Basque Country; B. cantabrica Boeters, 1983, in Asturias, Cantabria, Basque Country, León, Burgos and Palencia; B. andalucensis, Boeters, 1983, in Jaén; B. galaica Boeters \& Rolán, 1988, in
Lugo; B. ovetensis Rolán, 1991, in Asturias and León; B. edmundi Boeters, 1984, in Mallorca; $B$. rolani Boeters, 1986, in Galicia and North of Portugal; B. lucensis Rolán, 1991, in Lugo, Orense and Asturias; B. asturica Boeters \& Rolán, 1988, in Asturias; B. montana Rolán, 1991, in Asturias, Cantabria, Basque Country and León.

World Distribution: Slovenia, Bosnia, Czech Republic, Austria, France, Italy and Spain (Peninsula and Balearic Islands).

BibliograPhY: Paladilhe, 1874; Boeters, 1983, 1984, 1986, 1988, 1995; Boeters \& Rolán, 1988; Radoman, 1983; Rolán, 1989, 1991; Haase, 2000; Falkner et al., 2001.

\section{Boetersiella Arconada \& Ramos, 2001}

TYPE SPECIES: Paludina sturmi Rosenhauer, 1856. TYPE LOCAlitY: Sierra Harana, Granada, Spain.

Diagnosis: Minute shell $(1-1.5 \mathrm{~mm})$ depressed trochiform or valvatiform; frontal and oval aperture with a thick columellar border that leaves a slit-like umbilicus; thin outer lip; peristome slightly oblique and adapically sinuate; ctenidium and gastric caecum totally absent; radula has a central tooth with one basal cusp on each side, female genitalia has a pedunculated bursa copulatrix and a sessile proximal seminal receptacle that leans over the bursa copulatrix; penis simple, unpigmented and cylindrical in transverse section; the base of the penis is widened in relation to its distal part and gradually tapered towards the tip.

SPECIES AND IBERO-BALEARIC DISTRIBUTION: Boetersiella sturmi in Jaén and Granada and $B$. davisi Arconada \& Ramos, 2001, in Granada.

WORLD DISTRIBUTION: Spain.

BIBliOgRAPHY: Rosenhauer, 1856; Boeters, 1988 (in part, see Arconada \& Ramos, 2001); Arconada \& Ramos, 2001.

\section{Chondrobasis Arconada \& Ramos, 2001}

TYPE SPECIES: Chondrobasis levantina Arconada \& Ramos, 2001.

Type LOCALity: San Miguel spring, Viver, Castellón, Spain.

Diagnosis: Minute shell $(1-1.5 \mathrm{~mm})$ trochiform or valvatiform; frontal and oval aperture with a slightly thickened columellar border that leaves a very narrow umbilicus; thin outer lip; the peristome is slightly oblique and adapically sinuate; ctenidium and gastric caecum totally absent; radula has 
a central tooth with one basal cusp on each side; female genitalia with a bursa copulatrix with no visible duct and a proximal sessile and pyriform seminal receptacle that leans tightly over the renal oviduct; penis unpigmented, cylindrical in transverse section, with a small, non-glandular papilla located in the concave side of the penis base; the slender distal part of the penis is markedly different in shape from the wider basal part.

SPECIES AND IBERO-BALEARIC DISTRIBUTION: Chondrobasis is a genus with only one known species, C. levantina, located in Castellón, Valencia, Alicante, Teruel and Cuenca provinces.

WORLD DISTRIBUTION: Spain.

BiBLIOGRAPHY: Boeters, 1981, 1988 (in part, as Hauffenia (Neohoratia) sturmi see Arconada \& Ramos, 2001); Arconada \& Ramos, 2001.

\section{Horatia Bourguignat, 1887}

TYPE SPECIES: Horatia klecakiana Bourguignat, 1887 TYPE LOCALITY: Spring near Ribaric, Cetina valley, Croatia.

DiAGNOSIS: Minute shell $(1-1.5 \mathrm{~mm})$; oval or rounded aperture; outer peristome simple, thin and straight; radula has a central tooth with one basal cusp on each side; gastric caecum absent; female genitalia with a pedunculated bursa copulatrix and two seminal receptacles; proximal receptacle bents and leans over the renal oviduct; penis, cylindrical in a transverse section, with a non-glandular penial lobe located in its middle inner edge.

SPECIES AND IBERO-BALEARIC DISTRIBUTION: Horatia gatoa Boeters, 1980, in Málaga. Two new species not yet described.

WORld Distribution: Croatia, Bosnia, Macedonia, Albania, Greece, Spain and Algeria.

Bibliography: Pollonera, 1898; Thiele, 1929; Radoman, 1969, 1983; Boeters, 1980, Gittenberger, 1982; Bole \& Velkovrh, 1986; Boeters, 1988; Ghamizi et al., 1997; Arconada, 2000; Bodon et al., 2001.

\section{Hydrobia Hartmann, 1821}

TYPE SPECIES: Cyclostoma acutum Draparnaud, 1805. TYPE LOCALITY: No specific locality is mentioned in the original description. According to Radoman (1977) the type locality is Étang du Prévost, Palavas, Mediterranean coast, in France.
DiAGNOSIS: shell conic; aperture ovoid, slightly rounded at the top; suture relatively shallow; umbilicus slit-like; radula has a central tooth with 1 or 2 basal cusps on each side; gastric caecum present; renal oviduct black pigmented; female genitalia has a well developed bursa copulatrix with a long duct and a distal seminal receptacle; penis flattened, pointed or with an enlarged, nearly round top angled to the left side. An outgrowth, more or less evident, on the left side of the penis.

SPECIES AND IBERO-BALEARIC DISTRIBUTION: Hydrobia (Hydrobia) acuta (Draparnaud, 1805), in Mallorca; H. (H.) minoricensis (Paladilhe, 1875) [= H. glyca (Servain, 1880) according to Boeters, 1988], in Cádiz, Mallorca and Menorca; H. (H.) atuca Boeters, 1988, in Mallorca; H. (H.) joossei Aartsen, Menkhorst \& Gittenberger, 1984, in south part of Portugal, Cádiz and Cantabria. Hydrobia (Peringia) ulvae (Pennant, 1777), in Cádiz, Pontevedra, Cantabria and south part of Portugal. In this paper we follow Haase's (1993) classification and consider Peringia Paladilhe, 1874 as a subgenus of Hydrobia.

WORLD DISTRIBUTION: In marine and brackish waters from North America, Europe, Northern Africa, Occidental Asia. Also cited in the Baltic sea, North sea, Black sea, Atlantic and Mediterranean.

BibliograPhy: Hershler \& Davis, 1980; Radoman, 1983; Giusti \& Pezzoli, 1984; Boeters, 1988, 1998; Haase, 1993.

\section{Islamia Radoman, 1973}

TYPE SPECIES: Horatia servaini Bourguignat, 1887 Type Locality: Near Sarajevo, Bosnia

DiAgNosis (according to Bodon et al., 2001): Minute shell $(0.5-1 \mathrm{~mm})$ ovoid to planispiral; radula has a central tooth with 1-2 basal cusps on each side; gastric caecum absent; female genitalia with two seminal receptacles; proximal receptacle larger than distal receptacle; bursa copulatrix absent; penis large, with a penial lobe on the inner edge of the penis, at half or near its distal end.

SPECIES AND IBERO-BALEARIC DISTRIBUTION: Islamia ateni (Boeters, 1969), in Lérida; I. schuelei Boeters, 1981, in Granada, Málaga, Almería and Cádiz; I. globulus lagari (Altimira, 1960), in Barcelona; I. globulus globulus (Bofill, 1909), in Lérida, Gerona and Huesca. Two species have been erroneously ascribed to this genus (Bodon et al., 2001), "I". azarum (Boeters \& Rolán, 1988), in Asturias and "I". coronadoi (Bourguignat, 1870), in Madrid. Another three new species are 
awaiting description (Arconada 2000; Arconada \& Ramos, submitted).

World DISTRIBUTION: Turkey, Israel, Balkanic Peninsula, Greece, Italy, France and Spain.

BIBLIOGRAPHY: Boeters, 1969; Radoman, 1973, 1978, 1983; Giusti et al., 1981; Bernasconi, 1984; Bodon et al., 1995, 2001; Schütt, 1991; Bodon \& Cianfanelli, 2002; Arconada \& Ramos, submitted.

\section{Mercuria Boeters, 1971}

TyPE SPECIES: Amnicola confusa Frauenfeld, 1863.

TYPE LOCALITY: South of France, no specific locality

DiAGNOSIS: Shell ovate-conic; ctenidium with 23-24 lamellae; radula has a central tooth with 1-2 basal cusps on each side; female genitalia has a sacciform and pedunculated bursa copulatrix and a proximal and sessile seminal receptacle; penis cylindrical, with a penial lobe located on the inner edge of the penis near its distal end, which is black pigmented.

SPECIES AND IBERO-BALEARIC DISTRIBUTION: Mercuria tachoensis (Frauenfeld, 1865), in northern and central part of Portugal; M. edmundi Boeters, 1986 in southern and central part of Portugal; M. balearica (Paladilhe, 1869), in Menorca and Granada and M. emiliana (Paladilhe, 1869), in Mallorca and Granada.

WORLD DISTRIBUTION: Morocco, Algeria, France, United Kingdom, Ireland, The Netherlands, Italy, Portugal and Spain (Peninsula and Balearic Islands).

Bibliography: Gassull, 1965; Paladilhe, 1869; Boeters, 1971, 1986, 1988; Van Damme, 1984; Falkner et al., 2001, 2002.

\section{Paladilhiopsis Pavlovic, 1913}

TYPE SPECIES: Paladilhia robiciana Clessin, 1882.

TyPe LOCAlity: Spring in Potoce, North of Kranj, Slovenia.

DiAGNOSIS: Shell conic, small (3-4 mm); oval and oblique aperture, with a sinuate outer lip; body completely unpigmented without ocular spots; radula has a central tooth with one basal cusp on each side; nervous system with long supraoesophageal and suboesophageal connectives; female genitalia has a big bursa copulatrix with a long and posteroventral duct; distal seminal receptacle small and with a long duct; penis simple, flattened, with a tapered distal end.

SPECIES AND IBERO-BALEARIC DISTRIBUTION: "Paladilhiopsis" septentrionalis Rolán \& Ramos,
1995, in Cantabria, Asturias, Basque Country and Burgos.

World Distribution: Slovenia, SerbiaMontenegro and Spain.

BiBliograPhy: Clessin, 1882; Radoman, 1983; Rolán \& Ramos, 1995; Rolán \& Arconada, 2003.

\section{Pseudamnicola Paulucci, 1878}

Type SPeCIEs: Bithynia lucensis Issel, 1866.

TYPE LOCALiTY: Bagni di Lucca, Tuscany, Italy.

DiagNosis: shell ovate; ctenidium with 18-23 lamellae; radula has a central tooth with one basal cusp on each side; renal oviduct black pigmented; small gastric caecum located in the posterior chamber of the stomach; female genitalia has a well developed bursa copulatrix and a small and proximal seminal receptacle; penis big, simple, widened in its base and generally pigmented.

SPECIES AND IBERO-BALEARIC DISTRIBUTION: Pseudamnicola (Corrosella) navasiana (Fagot 1907), in Zaragoza; P. (C.) falkneri Boeters 1970, in Granada, Guadalajara and Castellón; $P$. (C.) luisi Boeters 1984, in Granada, Almería and Jaén; $P$. (C.) hinzi Boeters 1986, in Burgos and Zaragoza; P. (C.) hydrobiopsis Boeters, 1999, in Granada; $P$. (Pseudamnicola) gasulli Boeters 1981, in Ibiza, Murcia and Almería, and P. (P.) spirata (Paladilhe, 1869), in Mallorca, Menorca and Gerona.

World Distribution: Morocco, Algeria, Balkanic Peninsula, Romania, Turkey, Belgium, The Netherlands, Germany, United Kingdom, France, Italy, Portugal and Spain (Peninsula and Balearic Islands).

BIBLIOGRAPHY: Paladilhe, 1869; Fagot 1907; Boeters 1970, 1971, 1981, 1984, 1986, 1988, 1999; Radoman, 1966; Van Damme, 1984; Ghamizi et al., 1997.

\section{Spathogyna Arconada \& Ramos, 2002}

TYPE SPECIES: Valvata (Tropidina) fezi Altimira, 1960

Type Locality: Fuente Roble, Yémeda, Cuenca, Spain. This locality has been proposed for inclusion into a Regional Plan for Microhabitats Conservation and Management in Castilla-La Mancha Region.

Diagnosis: Shell minute $(<1 \mathrm{~mm})$, valvatiform o trochiform, wide umbilicus; ctenidium with 10 lamellae, approximately; radula has a central tooth with one basal cusp on each side; gastric caecum absent; female genitalia has a small bursa copula- 
trix with a long duct and two seminal receptacles; penis unpigmented with a non glandular lobe located in a medial position.

SPECIES AND IBERO-BALEARIC DISTRIBUTION: Spathogyna fezi (Altimira, 1960) in Cuenca and Castellón.

WORLD DISTRIBUTION: Spain.

Conservation: Spathogyna fezi is included in the Castilla-La Mancha Regional List as being of "Special Interest" and has also recently been proposed for inclusion in the National List of Endangered Species, as "critically endangered".

Bibliography: Altimira, 1960; Binder, 1966; Boeters, 1988; Bodon et al., 2001; Arconada \& Ramos, 2002.

\section{Tarraconia Ramos \& Arconada, 2000}

TYPE SPECIES: Hauffenia (Neohoratia) gasulli Boeters, 1981.

TyPE Locality: El Bañador, Altura, Castellón, Spain.

DiAGNOSIS: Minute, valvatiform and depressed shell $(1.5 \mathrm{~mm})$; aperture rounded and straight, with a characteristic and marked varix behind the outer lip; ctenidium with 11-18 lamellae; radula has a central tooth with one basal cusp on each side; suboesophageal connective absent; gastric caecum absent; female genitalia with a large and pedunculated bursa copulatrix; seminal receptacles absent (their function is undertaken by a thickened portion of the renal oviduct); penis with a medium-sized, non-glandular and roundish lobe located in its middle inner edge.

SPECIES AND IBERO-BALEARIC DISTRIBUTION: Tarraconia gasulli in Castellón and Valencia; T. rolani Ramos, Arconada \& Moreno, 2000, in Tarragona.

WORLD DISTRIBUTION: Spain.

BIBLIOGRAPHY: Boeters, 1988; Ramos et al., 2000.

\section{Distribution patterns and ecology of Hydrobiidae in Europe}

Some spectacular speciation phenomena of hydrobiids have been observed in very diverse geographic areas [(e.g., in Coahuila, México (Hersler, 1985), the Patagonia (Pilsbry, 1911) and Southwest Australia (Ponder et al., 1993)]. The majority of European hydrobiids have a circunmediterranean distribution that encompasses three regions: The Balkanic, Italian and Iberian Peninsulas. These regions could be considered "evolutionary centres"
(Davis 1982), especially for stygophiles species having valvatiform morphology (Radoman, 1983; Bole \& Velkovrh, 1986; Bodon et al., 2001). In other words, these are areas with a concentration of highly diverse faunas that consist of at least one or more monophyletic groups. In Europe, Hydrobiid diversity was first studied on the Balkanic Peninsula. Around 190 species alone were described in Lake Ohrid, in the border region between Macedonia and Albania (Radoman, 1983).

This circunmediterranean distribution is probably the result of successive dispersal, vicariance, speciation and extinction processes that took place during the Eocene-Miocene. Differences between European and North American faunas suggest that the radiation occurred subsequent to the Eocene, since during this period a palaeographic connection existed between these territories that still permitted migratory flow between both continents. This continental link with America was lost during "The Terminal Eocene Event" (Eocene-Oligocene transition), at the same time that new land connections between Europe and Asia were being formed. The distribution of contemporary faunas is a result of both this event and of the climatic and physiographic changes that have occurred in Europe since the Lower Oligocene (Barbadillo et al., 1997).

Essentially, the present-day distribution of Hydrobiidae can be explained by three main palaeographic events: 1) dispersal movements originating in Eurasia - especially those via Asia Minor - that are evinced by the distribution of some contemporary genera, such as Horatia and Islamia; 2) immigrations emanating from North Africa that could explain the current distribution of genera like Belgrandia and Pseudamnicola, and; 3 ) the effects of recent, alternating glacial and interglacial periods. The first event occurred at the upper Miocene during which time there was an exchange of Eurasian faunas across a stable continental corridor (Steininger \& Rögl, 1984). These dispersal movements could have extended across Turkish, Balkanic and Italian territory into the Iberian Peninsula given that, at that time, the Pyrenees were relatively low and did not apparently constituted a major geographic barrier (Barbadillo et al., 1997). The second dispersal event, which played an important role in the evolutionary history of the fauna of the Iberian Peninsula, took place approximately 6MYA (Jong, 1998) across Northern Africa with the formation of the massive Betic-Rifean (Busack, 1986). The subsequent opening and flooding of the Strait of Gibraltar is responsible for the vicariance and taxonomical differentiation phenomena that are observed in many of the faunistic groups on either 
side of the Strait (Ghamizi et al., 1997). Applying a molecular clock to the phylogenetic analysis of Iberian valvatiform hydrobiids reveals that the beginning of their diversification coincides with the opening of the Strait (Arconada, 2000). The third palaeographic event dates to more recent times and occurred at the same time as alternating glacial and interglacial periods (700,000 years - present day). The strong climatic oscillations caused by these glacial processes limited the survival possibilities of many species (Hewitt, 1996). During these glacial periods, Southern Mediterranean Europe resisted the advancing ice, and many refuges were created that helped some species survive. These regions that correspond with the three described evolutionary centres, sheltered some of the more northern populations that would have otherwise been extinguished.

The high hydrobiid diversity on the three peninsulas as well as the pronounced circummediterranean distribution of a majority of the studied taxa could be explained by the combination of: 1) faunistic exchanges via the previously mentioned dispersal routes, 2) the refuge effect caused by glacial processes in Southern Mediterranean Europe, and 3) the difficulties inherent in hydrobiid dispersal. There are numerous descriptions of endemisms and a general lack of taxonomic nexus among these peninsulas. To test if the observed phylogenetic discontinuity is a real phenomenon or simply the result of incomplete sampling, greater effort needs to be made to locate and study new hydrobiid populations.

In general, the natural habitats of the species of this family are cool inland bodies of water that are well oxygenated and have a constant, moderate flow throughout the year. These include streams, ponds, springs, pools, and subterranean waters. Stygobiont species make up almost all the molluscs fauna associated with subterranean continental waters (Bole \& Velkovrh, 1986). Hydrobiids are indicator species of water quality and contamination levels, and have also been used as "witnesses" to reveal palaeographic relationships between different hydrological basins (Radoman, 1983). In certain geographic areas, this family has experienced some notable speciation phenomena related to population fragmentation and habitat isolation (in some cases within the same hydric system). Of all the dispersal mechanisms previously mentioned for hydrobiids that inhabit springs, etc., the most common is via accidental introduction by vegetative or animal vectors, such as mammals, birds and insects (Davis, 1982; Ponder, 1982). It is suspected that some distribution patterns of freshwater molluscs coincide with migratory bird routes (Russell-Hunter, 1979).
Subterranean aquatic systems may also be effective dispersal conduits, as in the case of the genus Bythiospeum, whose eggs are dragged underground to other hydric systems or dispersed by subterranean aquatic insects (Boeters, 1998). Other more unusual dispersal pathways include floods and windassisted aerial dispersal (Ponder et al., 1989).

Ibero-balearic hydrobiid species, and hydrobiids in general, exhibit similar reproductive strategies. They have separate sexes and they cross-fertilize. Females store the sperm in seminal receptacles for an indefinite period of time; in some documented cases up to one year. The female lays a varying number of ovigerous capsules (many in the case of Hydrobia and Pseudamnicola and very few in the majority of valvatiform species). Development of these capsules is direct and lecitotrophic, that is, they contain an embryo that is nourished by its own yolk and other intracapsular nutrients. Upon hatching, the egg releases a bentonic juvenile in an advanced stage of development. Even though few offspring are produced in this type of reproductive strategy, their probability of survival is increased because the planctotrophic phase (a phase of elevated mortality) is eliminated. Otherwise, the dispersal capacity of species with bentonic juveniles is significantly reduced in comparison to those with planctonic larvae. Ovigerous capsules can remain attached to vegetation or even to the shells of their progenitors. As an exception, Hydrobia ulvae has a different reproductive strategy. It produces small and numerous eggs than other Hydrobia species, and releases free living veligers (Fretter \& Graham, 1994). Only one species, Potamopyrgus antipodarum originally from New Zealand, exhibits parthenogenetic reproduction. In principle, this means that it would take only specimen to establish a new colony. This reproductive strategy explains how this invasive species has conquered a great number of freshwater environments on practically all the continents of the world.

\section{Hydrobiidae distribution and ecology in the Ibero- balearic region}

The high endemicity of Iberian Hydrobiidae is very likely related to former processes of geographic isolation and hydrobiids limited dispersal capacity. On some occasions, sympatric populations of congeneric taxa have been found. But in none of these instances have hybridisation, flow phenomena, or genetic introgression been observed.

Some genera show signs of a continuous distribution. For example, Belgrandiella occupies an 


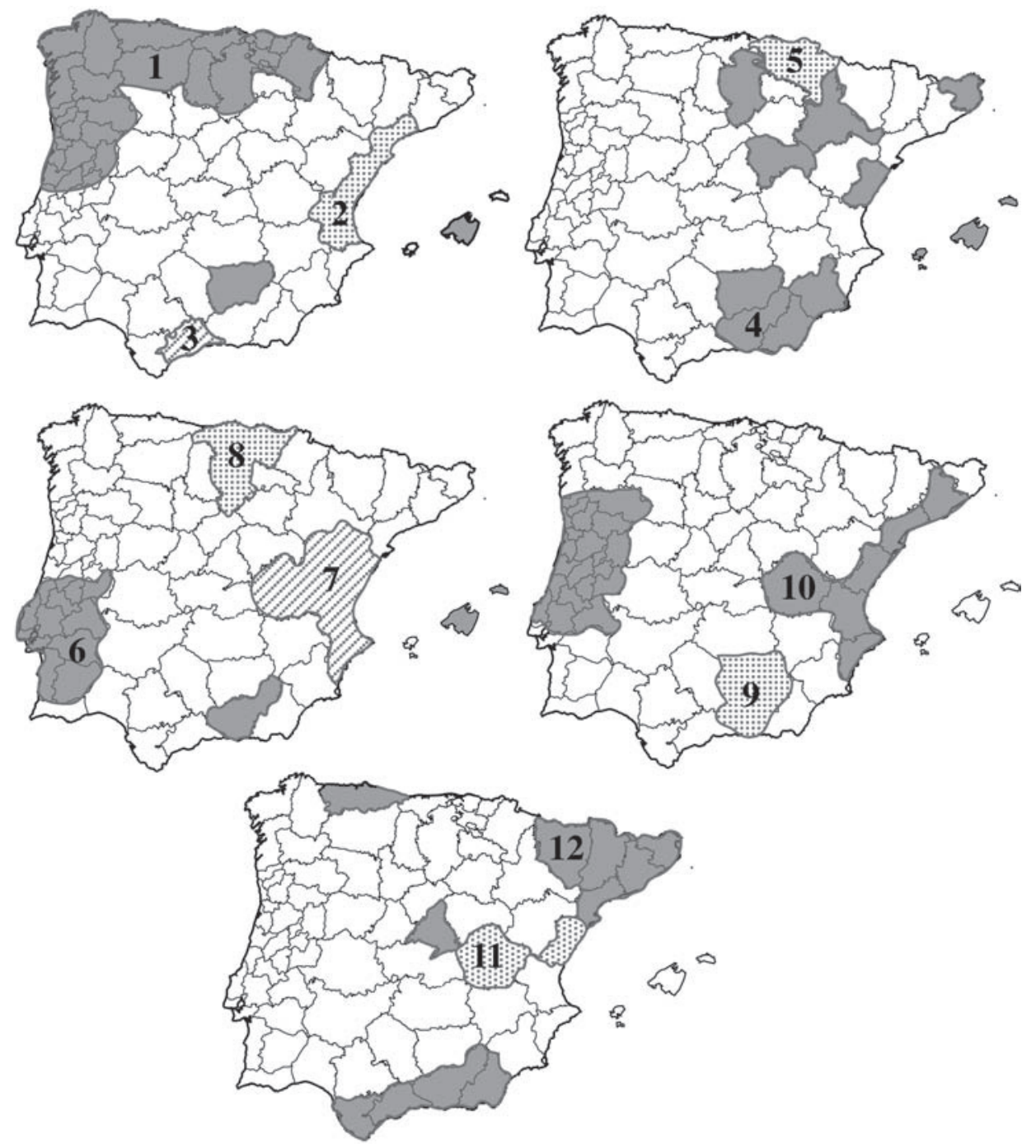

Fig. 1. - Distribution of freshwater hydrobiids by Ibero-balearic provinces. Similar shaded areas represent the same taxa. 1Belgrandiella; 2- Tarraconia; 3- Horatia, 4- Pseudamnicola; 5- Alzoniella; 6- Mercuria; 7- Chondrobasis; 8- Paladilhiopsis; 9Boetersiella; 10- Belgrandia; 11- Spathogyna; 12- Islamia.

Fig. 1.- Distribución de los hidróbidos ibero-baleares de agua dulce por provincias. Tramas similares representan a los mismos taxones. 1- Belgrandiella; 2- Tarraconia; 3- Horatia, 4- Pseudamnicola; 5- Alzoniella; 6- Mercuria; 7- Chondrobasis; 8Paladilhiopsis; 9- Boetersiella; 10- Belgrandia; 11- Spathogyna; 12-Islamia.

extensive area in the North-Northwest region of the Peninsula. Only two species, B. andalucensis and $B$. edmundi, have been reported outside this region (in Jaén and Mallorca, respectively). The same can be said of the genera Chondrobasis and Tarraconia. Nevertheless, many other genera have a disjunctive distribution and occupy extensive territories that are geographically separated from each other. Species of the genus Belgrandia, for example, are found along both the eastern and western areas of the Peninsula.
Other examples are Islamia, Mercuria and Pseudamnicola. Islamia has a broad distribution throughout the Northern Mediterranean Basin. Groups of species from this genus have been described which inhabit geographically separated areas and show some anatomical differences. This, probably suggests the existence of distinct branches in the radiation of Islamia (Bodon et al., 2001). Mercuria species are scattered over a broad area that includes the West Mediterranean Basin and West 
continental Europe. According to published records, species of Pseudamnicola are scattered throughout the western half of the Peninsula and in the Balearic Islands. However, our own data, yet unpublished, suggest that the distribution of this genus is more continuous. While we consider our sampling to have been relatively satisfactory, a more detailed study of numerous populations is pending. Some of the above-mentioned species that display an "aberrant" distribution may need to be assigned to new genera following a meticulous study of their morphology.

In summary, Iberian hydrobiids are distributed throughout the Iberian Peninsula and Balearic Islands but there are areas, such as the Mediterranean region, which are particularly rich in valvatiform hydrobiids (Fig. 1). The north-northwestern part of the Peninsula is also noteworthy for the speciation phenomena that occurred in the genus Belgrandiella. Although some of the Iberian genera described to date are endemic (e.g., Boetersiella, Chondrobasis, Spathogyna and Tarraconia), the rest are distributed throughout the circunmediterranean region (e.g., Islamia). Some, like Pseudamnicola, Mercuria and Belgrandia, also extend into Northern Europe.

To understand the present-day geographical distribution of Hydrobiidae it is necessary to study factors such as: reproductive strategies, body size, ecophysiological demands and the ecological constraints imposed upon them by their habitats. Species of Ibero-balearic hydrobiids that are highly sensitive to their environment are restricted in their ability to extend into new regions that are frequently colonised by taxa (e.g., Pseudamnicola and Mercuria) that are more tolerant to limiting factors (e.g., pollution).

The majority of hydrobiids live in ecosystems that are rich in diversity but fragile in terms of conservation. Many hydrobiids have restricted ranges or are confined to small areas, and sometimes to a single stream. This is especially true of many endemic species. Hydrobiid habitats are frequently integrated into human-influenced environments and submitted to constant disturbances that challenge organismal survival. Waste accumulation, pollution spills, and habitat alteration are the most common causes of extinction for peninsular hydrobiid populations. Despite their close connection with man, these organisms are still largely unknown due to their minute size (between 1-8 $\mathrm{mm}$ ) and highly simplified anatomical structure. The systematic study of these molluscs carried out over the last years makes it clear that: 1) their faunistic richness is enormous and, 2) there are yet many taxa to be described in these poorly-studied taxonomic groups. Several hydrobiid populations and species have already disappeared and it has been recommended that several of the more threatened species be included in the Catálogo Nacional de Especies Amenazadas (Alonso et al., 2001). But further studies of the biological diversity and geographic distribution of Iberian hydrobiids are urgently called for in order that more mechanisms can be put into place that will guarantee their conservation and long-term survival.

\section{ACKNOWLEDGEMENTS}

In memory of our beloved colleague, Fermín Martín Piera, for his enthusiasm and the contribution he made to biogeographical studies of the Iberian Peninsula. We also would like to give special thanks to R. Araujo, D. Buckley and A. Machordom for helping to improve this manuscript. James Watkins and the authors of this paper revised the English text.

\section{References}

Alonso, M. R., Altonaga, K., Álvarez R. M., Araujo, R., Arconada, B., Arrébola, J. R., Bech, M., Bros, V., Castillejo, J., Gómez, B., IbÁñez, M., LuQue, A., Martínez Ortí, A., Moreno, D., Prieto, C., Puente, A. I., Pujante, A. M., Robles, F., Rolán, E. \& TEMPlado, J. (por orden alfabético), 2001. Protección de moluscos en el Catálogo Nacional de especies amenazadas. Reseñas Malacológicas, 11: 1-386.

Altimira, C., 1960. Contribución al conocimiento de los moluscos terrestres y de agua dulce de Cataluña. Miscelánea Zoológica, 1(3): 9-15.

ArconAdA, B., 2000. Contribución al conocimiento sistemático y filogenético de la familia Hydrobiidae en la península Ibérica. Tesis doctoral. Universidad Autónoma de Madrid. 447 pp.

ArconadA, B. \& Ramos, M. A., 2001. New data on Hydrobiidae systematics: two new genera from the Iberian Peninsula. Journal of Natural History, 35: 949-984.

ArconadA, B. \& Ramos, M. A., 2002. Spathogyna, a new genus for Valvata (? Tropidina) fezi Altimira, 1960 from eastern Spain: a second case of natural pseudohermaphroditism in a Hydrobiidae species (Mollusca, Prosobranchia). Journal of Molluscan Studies, 68: 319-327.

Arconada, B. \& Ramos, M. A., The species of the genus Islamia (Gastropoda, Prosobranchia, Hydrobiidae) in the Iberian Peninsula. Malacologia (submitted).

Azpeitia, F. A., 1935. Conchas univalvas terrestres de España y Portugal. Géneros: Paludina, Bithynia y Amnicola. Revista de la Academia de Ciencias de Madrid, 32(2): 255-320.

Barbadillo, L. J., García-París, M. \& SAnchiz, B., 1997. Orígenes y relaciones evolutivas de la herpetofauna ibérica. In: J. M. Pleguezuelos (ed.). Distribución y 
Biogeografía de los anfibios y reptiles en España y Portugal. Universidad de Granada y Asociación Herpetológica Española. Granada: 45-100.

BECH, M., 1990. Fauna malacológica de Catalunya. Molluscs terrestres i d'aigua dolça. Treballs de la Institució Catalana d'Història Natural, 12: 1-229.

Bernasconi, R., 1984. Hydrobides de France: Moitessieria, Bythiospeum et Hauffenia des départments gard, Ain, Isère (Gastéropodes, Prosobranches). Revue Suisse de Zoologie, 91(1): 203-215.

Bernasconi, R., 1992. Systematics of Hydrobiidae (Gastropoda Prosobranchia Monotocardia Rissoacea): A compendious survey with proposals for an improved classification. Privately published. Münchenbuschsee. 14 pp.

Binder, E., 1966. Position systematique de Valvata minuta Drap., Valvata globulina Palad. et d'autres petites espèces attribuées au genre Valvata. Atti della Società Italiana di Scienze Naturali e del Museo Civico di Storia Naturale di Milano, 105: 371-376.

Bodon, M., 1988. Note anatomiche su "Belgrandiella" hartwigschuetti" Reischütz e revisiones della sua posizione sistematica (Gastropoda: Prosobranchia: Hydrobiidae). Archiv für Molluskenkunde, 119(1/3): 55-63.

Bodon, M. \& Cianfanelli, S., 2002. Idrobiidi Freatobi del Bacino del Fiume Magra (Liguria-Toscana) (Gastropoda: Prosobranchia: Hydrobiidae). Bolletino Malacologico, 38(1-4): 1-30.

Bodon, M. \& Giusti, F., 1991. The genus Moitessieria in the island of Sardinia and in Italy. New data on the systematics of Moitessieria and Paladilhia (Prosobranchia: Hydrobiidae). Malacologia, 33: 130.

Bodon, M., Manganelli, G., Sparacio, I. \& Giusti, F., 1995. Two new species of the genus Islamia Radoman, 1973 from Italian islands (Prosobranchia: Hydrobiidae). Journal of Molluscan Studies, 61(1): 43-54.

Bodon, M., Manganelli, G. \& Giusti, F., 2001. A survey of the European valvatiform Hydrobiid genera with special reference to Hauffenia Pollonera, 1898 (Gastropoda: Hydrobiidae). Malacologia, 43(1-2): 103-215.

Boeters, H. D., 1969. Pseudamnicola klemmni n. sp. aus Südfrankreich und Microna ateni $\mathrm{n}$. sp. aus den spanischen Pyrenäen (Mollusca, Prosobranchia). Archiv für Molluskenkunde, 99(1/2): 69-72.

Boeters, H. D., 1970. Corrosella n. gen. (Prosobranchia, Hydrobiidae). Journal de Conchyliologie, 108(3): 63-69.

Boeters, H. D., 1971. Pseudamnicola Paulucci, 1878 und Mercuria n. gen. (Prosobranchia, Hydrobiidae). Archiv für Molluskenkunde, 101(1-4): 175-181.
Boeters, H. D., 1980. Unbekannte westeuropäische Prosobranchia, 3. Basteria, 44: 61-64.

Boeters, H. D., 1981. Unberkannte westeuropäische Prosobranchia, 2. Archiv für Molluskenkunde, [1980], 111(1/3): 55-61.

Boeters, H. D., 1983. Unbekannte westeuropäische Prosobranchia, 5. Archiv für Molluskenkunde, 114(1/3): 17-24.

Boeters, H. D., 1984. Unbekannte westeuropäische Prosobranchia, 6. Heldia, 1(1): 9-11.

Boeters, H. D., 1986. Unbekannte westeuropäische Prosobranchia, 7. Heldia, 1(4): 125-128.

Boeters, H. D., 1988. Moitessieriidae und Hydrobiidae in Spanien und Portugal (Gastropoda, Prosobranchia). Archiv für Molluskenkunde, 118(4/6): 181-261.

Boeters, H. D., 1995. Belgrandiella aus einem holozanen Kalktuff in Oberfranken (Prosobranchia: Hydrobiidae). Heldia, 2(3-4): 69-72.

Boeters, H. D., 1998. Susswasserfaun von Mitteleuropa. Band 5/1-2. (Mollusca: Gastropoda: superfamilie Risooidea). Gustav Fischer, Stuttgart, Jena. 76 pp.

Boeters, H. D., 1999. Alzoniella navarrensis n. sp., Pseudamnicola (Corrosella) hydrobiopsis n. sp. and the type species of Pseudamnicola Paulucci, 1877. Unknown West European Prosobranchia, 9. Basteria, 63: 77-81.

Boeters, H. D., 2000. The genus Alzoniella Giusti \& Bodon, 1984 in France. West European Hydrobiidae, 9 (Gastropoda, Prosobranchia). Basteria, 64: 151-163.

Boeters, H. D., 2001. A contribution to the knowledge of Alzoniella Giusti \& Bodon 1984 in France. Unknown Westeuropean Prosobranchia, 13. Archiv für Molluskenkunde, 129(1/2): 149-156.

Boeters, H. D. \& Rolán, E., 1988. Unknown West European prosobranchs, 9. Some new Spanish freshwater prosobranchs. Basteria, 52: 197-202.

BofILl, A., 1909. El Noguera Ribagorzana "Vallis Clausa" malacológicamente considerado. Actas y Memorias del Primer Congreso de Naturalistas Españoles, Zaragoza: 190-260.

Bofill, A. \& HAAs, F., 1920. Estudi sobre la malacologia de les valls pirenaiques, II. Vall del Noguera Ribagorçana. Treballs del Museu de Ciènces Naturals de Barcelona, 3(1): 1-99, 2 mapas, 3 láms.

Bole, J. \& Velkovrh, F., 1986. Mollusca from continental subterranean aquatic habitats. In: L. Botosaneanu (ed.). Stygofauna Mundi. Brill. Leiden: 177-208.

Boss, K. J., 1971. Critical estimate of the number or recent mollusca. Occasional Papers on Molluscs, 3(40): 81-135.

BUSACK, S. D., 1986. Biogeographic analysis of the herpetofauna separated by the formation of the Strait of Gibraltar. National Geographic Research, 2(1): 17-36. 
Clessin, S., 1882. Eine österreichische Paladilhia. Malakozoologische Blätter, Cassel, N. F., 5: 130-131.

DAvIS, G. M., 1979. The origin and evolution of the gastropod family Pomatiopsidae, with emphasis on the Mekong river Triculinae. Academy of Natural Sciences of Philadelphia, Monograph, 20: 1-120.

DAvis, G. M., 1982. Historical and ecological factors in the evolution, adaptative radiation and biogeography of freshwater mollusks. American Zoologist, 22(2): 375-395.

Davis, G. M., Kuo, Y.-H., Hoagland, K. E., Chen, P.-L., YANG, H.-M. \& CHEN, D. J., 1985. Erhaia, a New Genus and New Species of Stenothyra (Prosobranchia: Rissooidea: Stenothyridae). Proceedings of the Academy of Natural Sciences of Philadelphia, 137: 48-78.

Davis, G. M., Wilke, T., Spolsky, C., QIU, C., Qiu, D., Xia, M., Zhang, Y. \& RosenberG, G., 1998. Cytochrome oxidase I-based phylogenetic relationships among the Pomatiopsidae, Hydrobiidae, Rissoidae and Truncatelliidae (Gastropoda: Caenogastropoda: Rissoacea). Malacologia, 40(1-2): 251-266.

FAGOT, P., 1887. Catálogo razonado de los moluscos del Valle de Artán. Crónica Científica, 10: 25-28; 49-54; 76-83.

FAGOT, P., 1905. Contribution à la faune malacológique de la Catalogne. Butlletí de la Institutió catalana d'Historia natural, 5: 122-124; 138-143.

FAGOT, P., 1907. Contribution à la faune malacologique de la province d'Aragon. Boletín de la Sociedad Aragonesa de Ciencias Naturales, 6: 136-160.

FAlkner, G., BANK, R. A. \& Proschwitz, T., 2001. Chek-list of the non-marine Molluscan Speciesgroup taxa of the States of Northern, Atlantic and Central Europe (CLECOM I). Heldia, 4(1/2): 1-76.

FAlkner, G., Ripken, Th. E. J. \& FAlKner, M., 2002. Mollusques continentaux de France. Liste de Référence annotée et Bibliographie. Patrimoines naturels, 52: 1-350.

FAlniowski, A. \& StefFeK, J., 1989. A new species of Bythiospeum (Prosobranchia: Hydrobioidea: Moitessieriidae) from southern Poland. Folia Malacologica Bulletin, 3: 95-101.

FAlniowski, A. \& Szarowska, M., 2000. Can poorly understood new characters support a poorly understood phylogeny? Shell-structure data in Hydrobiid systematics (Mollusca: Gastropoda: Prosobranchia: Hydrobiidae). Journal of Zoological Systematics and Evolutionary Research, 33: 133-144.

Fretter, V. \& Graham, A., 1994. British Prosobranch Molluscs. Their functional anatomy and ecology. The Ray Society. London. 820 pp.

Gasull, L., 1965. Algunos moluscos terrestres y de agua dulce de Baleares. Bolletí de la Societat d'Historia Natural de les Balears, 11(1-4):1-161.
GASULL, L., 1971. Fauna malacológica de las aguas continentales dulces y salobres del suereste Ibérico. Bolletí de la Societat d'Historia Natural de les Balears, 16: 24-94.

GASUlL, L., 1981. Fauna malacológica terrestre y de agua dulce de la provincia de Castellón de la Plana. Bolletí de la Societat d'Historia Natural de les Balears, 25: 55-102.

Ghamizi, M., VAla, J.C. \& BouKA, H., 1997. Le genre Pseudamnicola au Maroc avec description de Pseudamnicola pallaryi n. sp. (Gastropoda: Hydrobiidae). Haliotis, 26: 33-49.

GitTenberger, E., 1982. Eine neue Horatia Art aus Griechenland (Prosobranchia, Hydrobiidae). Basteria, 46: 68.

Giusti, F. \& Bodon, M., 1984. Notulae Malacologicae, XXXI. Nuove Hydrobiidae dell'Italia nord-occidentale (Gastropoda: Prosobranchia). Archiv für Molluskenkunde, [1983], 114(4/6): 157-181.

Giusti, F. \& Pezzoli, E., 1982. Notes on the small Hydrobioidea in Italian subterranean waters: catalogue, biogeography and some systematic problems. Malacologia, 22(1-2): 463-468.

Giusti, F. \& Pezzoli, E., 1984. Notulae Malacologica XXIX. Gli Hydrobiidae salmastri delle acque costiere Italiane: Primi cenni sulla sistematica del gruppo e sui caratteri distintivi delle singole morfospecie. Lavori della Società Italiana di Malacologia, 21: 117-148.

Giusti, F., Pezzoli, E. \& Bodon, M., 1982. Notulae Malacologicae, XXVIII. Primo contributo alla revisione del genere Islamia (Radoman, 1973) in Italia. Lavori della Società Malacologica Italiana (Atti del $\mathrm{V}^{\mathrm{o}}$ Convegno, Pavia): 49-71, 7 plates.

Golikov, A. N. \& Starobogatov, Y. I., 1975. Systematics of prosobranch gastropods. Malacologia, 15(1): 185-232.

HAAS, F., 1924. Contributió a la malacofauna de la conca inferior del Ebre: Butlletí de la Institució Catalana d'Historia Natural, 2a serie, 4(6): 48-63.

HAAS, F., 1925. Beitrage zur molluskenfauna Kataloniens zusätze und Berichtigungen. Archiv für Molluskenkunde, 57: 234-240.

HAAs, F., 1927. Paludina sturmi Rosenhauer, iene vergessene paläarktische Schnecke. Archiv für Molluskenkunde, 59: 157-158.

HaAse, M., 1993. The genetic differentiation in three species of the genus Hydrobia and systematic implications (Caenogastropoda, Hydrobiidae). Malacologia, 35: 389-398.

HAASE, M., 2000. A review of the genus Belgrandia with the description of new species from France (Caenogastropoda: Hydrobiidae). Malacologia, 42(1): 171-201.

Hersler, R. 1985. Systematic revision of the Hydrobiidae (Gastropoda: Rissoacea) of the Cuatro 
Ciénagas Basin, Coahuila, México. Malacologia, 26: 31-123.

Hershler, R. \& DAvis, G. M., 1980. The morphology of Hydrobia truncata (Gastropoda: Hydrobiidae): relevance to systematics of Hydrobia. Biological Bulletin, 158: 195-219.

HewitT, G. M., 1996. Some genetic consequences of ice ages, and their role in divergence and speciation. Biological Journal of the Linnean Society, 58: 247-276.

Hutchinson, G. E., 1993. Gastropods molluscs. In: G. E. Hutchinson \& Y. H. Edmonson (eds.). A treatise on Limnology. Volume IV. The Zoobenthos. John Wiley \& Sons. London: 125-275.

JONG, H. DE, 1998. In search of historical biogeographic patterns in the western Mediterranean terrestrial fauna. Biological Journal of the Linnean Society, 65: 99-164.

Kabat, A. R. \& Hersler, R., 1993. The Prosobranch family Hydrobiidae (Gastropoda: Rissooidea): Review of classification and supraspecific taxa. Smithsonian Contributions to Zoology, 547: 1-94, 4 Tables.

Knight, J. B., Batten, R. L., Yochelsen, E. L. \& Cox, L. R., 1960. Supplement, Paleozoic and some Mesozoic Caenogastropoda and Opisthobranchia. In: R. C. Moore (ed.). Treatise on invertebrate paleontology, Part 1, Mollusca 1. Geological Society of America \& University of Kansas Press. New York \& Lawrence: I310-I331.

Kristensen, T. K., 1985. Guide pratique des Gastéropodes d'eau douce Africains. 7. Èspeces présentes en Afrique du Nord-Ouest. Danish Bilharziosis Laboratory. Charlottenlund. $30 \mathrm{pp}$.

Morrison, J. P. E., 1949. The cave snails of Eastern North America. The American Malacological Unión, News Bulletin and Annual Report, for 1948: 13-15.

Morrison, J. P. E., 1971. Names for the subfamily Hydrobiinae. American Malacological Union, Annual Reports for 1970, 37: 7-8.

NoRDSIECK, F., 1972. Die europäischen Meeresschencken (Opistobranchia mit Pyramidellidae; Rissoacea) vom Eismeer bis Kapverden, Mittelmeer und Schwarzes Meer. Gustav Fischer Verlag. Stuttgart. 327 pp.

Paladilhe, A., 1869. Nouvelles miscellanées malacologiques. Revue et Magazine de Zoologie Pure et Apliquée, (2), 19: 38-53; 88-95.

Paladilhe, A., 1874. Monographie du nouveau genre Peringia, suivie des descriptions d'espèces nouvelles de Paludinées françaises. Annales des Sciences Naturelles, Séries 6, Zoologie et Paléontologie, 1(1): $1-38$, plate 3 .

Pilsbry, H. A., 1911. Non-marine Mollusca of Patagonia. Reports of Princenton University Expeditions to Patagonia, 1896-1899, 3(5): 513-633, plates 38-47.
Pollonera, C., 1898. Intorne ad alcune Conchiglie del Friuli. Bollettino dei Musei di Zoologi ed Anatomia comparata della Università di Torino, 13(334): 1-4.

Ponder, W. F., 1982. Hydrobiidae of Lord Howe Island (Mollusca: Gastropoda: Prosobranchia). Australian Journal of Marine and Freshwater Research, 33(1): 89-159.

Ponder, W. F., 1988. The Truncatelloidean (=Rissoacean) radiation- A preliminary phylogeny: Prosobranch phylogeny. Malacological Review, Supplement, 4: 129-164.

Ponder, W. F., Clark, G. A., Miller, A. C. \& Toluzzi, A., 1993. On a major radiation of freshwater snails in Tasmania and eastern Victoria: a preliminary overview of the Beddomeia group (Mollusca: Gastropoda: Hydrobiidae). Invertebrate Taxonomy, 5: 501-750.

Ponder, W. F., Hersler, R. \& Jenkins, B. J., 1989. An endemic radiation of Hydrobiid snail from artesian springs in Northern South Australia: their taxonomy, physiology, distribution and anatomy. Malacologia, 31(1): 1-140.

Ponder, W. F. \& WARÉn, A., 1988. Appendix: Classification of the Caenogastropoda and Heterostropha -A list of the family-group names and higher taxa: Prosobranch phylogeny. Malacological Review, Supplement, 4: 288-326.

Radoman, P., 1966. Die Gattungen Pseudamnicola und Horatia. Archiv für molluskenkunde, 95(5/6): 243-253.

RADOMAN, P., 1969. On the taxonomy and Biogeography of Hydrobiidae. Malacologia, 9(1): 173-177.

Radoman, P., 1973. Contribution à la connaissance des gastéropodes des eaux douces de Bosnie et d'Herzegovine. Bulletin du Muséum d'Histoire Naturelle de Marseille, 33: 227-237.

Radoman, P., 1978. Nov Rod Pseudoislamia i novi Predstavnici Rodova Islamia i Parabythinella. Bulletin du Muséum d'Histoire Naturelle de Belgrade, série B, livre 33: 23-27.

Radoman, P., 1983. Hydrobiodea, a Superfamily of Prosobranchia (Gastropoda), I Systematics. Serbian Academy of Sciences and Arts Monographs, 547, Department of Sciences, 57. Beograd. ii + 256 pp., 12 plates.

Ramos, M. A., Arconada, B., Rolán, E. \& Moreno, D., 2000. A new genus and a new species of Hydrobiid snail (Mollusca: Gastropoda: Hydrobiidae) from Eastern Spain. Malacologia, 42(1): 75-101.

ReIschutz, P. L., 1983. Beiträge zur Molluskenfauna Niederösterreichs 4. Neue Taxa niederösterreichischer Hydrobioidea (Gastropoda). Malakologische Abhandlungen, 8(12): 149-154.

Rolán, E., 1989. Aportaciones al conocimiento de Belgrandiella rolani Boeters, 1986 (Gastropoda, Hydrobiidae). Publicaçoes Ocasionais da Sociedade Portuguesa de Malacologia, (13): 51-62. 
RolÁN, E., 1990. Belgrandia lusitanica (Paladilhe, 1867) (Gastropoda: Hydrobiidae), especie endémica de Portugal, en riesgo de extinción. Publicaçoes Ocasionais da Sociedade Portuguesa de Malacologia, 15: 11-16.

RolÁN, E., 1991. El género Belgrandiella Wagner, 1927 en el norte de la Península Ibérica con descripción de tres especies nuevas (Mollusca, Gastropoda, Hydrobiidae). Thalassas, 9: 99-122.

Rolán, E. \& ArConAdA, B., 2003. Nueva información sobre Paladilhiopsis septentrionalis (Mollusca, Prosobranchia). Boletín de la Sociedad Española de Malacología (en prensa).

Rolán, E. \& Ramos, M. A., 1995. Una nueva especie de Hydrobiidae (Mollusca, Prosobranchia) del norte de la Península Ibérica. Iberus, 13(2): 119-127.

Rosenhauer, W. G., 1856. Die Thiere Andalusiens nach dem Resultate einer Reise zusammengeotellt, nebst den Beschreibungen von 249 neuen oder bis jetzt noch unbeschriebenen Gattungen und Arten. Theodor Blaesing. Erlangen. 360 pp.

Russell-Hunter, W. D., 1979. Ecology of freshwater pulmonates. In: V. Fretter \& J. Peake (eds.). Pulmonates, vol. 2A. Academic Press. London: 335383.

SchÜTT, V. H., 1961. Das genus Horatia Bourguignat. Archiv für Molluskenkunde, 90(1-3): 69-77.

SchÜTт, V. H., 1991. A contribution to the knowledge of some inland water hydrobiid snails in Israel (Gastropoda, Prosobranchia). Basteria, 55(4-6): 129137.

Starobogatov, Y. I., 1970. Fauna molliuskov i zoogeograficheskoe raionirovanie kontinental'nych vodoemov zemnogo shara [Fauna of Molluscs and Zoogeographical separation into districts of the continental water reservoirs of the world.] Zoologicheskii Institut, Akademiia Nauk SSSR. Leningrad. 372 pp. (in Russian).

Starobogatov, Y. I. \& Sitnikova, T. Y., 1983. [Sistema otryada Littoriniformes (Gastropoda Pectinibranchia).] In: I. M. Likharev (ed.). Molliuski, sistemati$k a$, ekologiia $i$ zakonomernosti raprostraneniia. Izdatel'stvo Nauka. Leningrad: 18-22 (in Russsian).

Steininger, F. F. \& RöGL, F., 1984. Paleogeography and palinspastic reconstruction of the Neogene of the Mediterranean and Paratethys. In: J. E. Dixon \& A. H. F. Robertson (eds.). The Geological Evolution of the Eastern Mediterranean. Blackwell Scientific Publication. Oxford: 659-668.
StimPSON, W., 1865. Diagnoses of Newly Discovered Genera of Gasteropods belonging to the subfam. Hydrobiinae, of the Family Rissoidae. American Journal of Conchology, 1(1): 52-54.

TAYlOR, D. W., 1966. A remarkable snail fauna from Coahuila, Mexico. Veliger, 9: 152-228.

TAYloR, D. W. \& Sohl, N. F., 1962. An outline of gastropod classification. Malacologia, 1(1): 7-32.

Thiele, J., 1929. Handbuch der systematischen Wiechtierkunde, 1(1). G. Fischer. Jena. 376 pp.

THOmpson, F. G., 1968. The aquatic snails of the family Hydrobiidae of Peninsular Florida. University of Florida Press. Gainesville. 268 pp.

Troschel, F. H., 1857. Das Gebiss der Schnecken zur begründung einer natürlichen Classification, 1(2). Berlin. pp. 73-112. Taf. 5-8.

TRYON, G. W., 1866. Review of "Researches upon the Hydrobiinae and Allied Forms". American Journal of Conchology, 2(2): 152-158.

VAn DAMme, D., 1984. The freshwater mollusca of northern Africa: Distribution, Biogeography and Palaeoecology. In: H. J. Dumont (ed.). Developments in hydrobiology, 25. W. Junk Publishers. Dordrecht. $176 \mathrm{pp}$.

WenZ, W., 1939. Gastropoda. Teil I: Allgemeiner Teil und Prosobranchia. In: O. H. Schindewolf (ed.). Handbuch der Paläozoologie, Bd. 6, Leif 3. Gebrüder Borntraeger. Berlin: 493-741.

Wilke, T. \& Davis, G. M., 2000. Infraspecific mitochondrial sequence diversity in Hydrobia ulvae and Hydrobia ventrosa (Hydrobiidae: Rissooidea: Gastropoda): do their different life histories affect biogeographic patterns and gene flow? Biological Journal of the Linnean Society, 70: 89-105.

Wilke, T., Davis, G. M., Falniowski, A., Giusti, F., Bodon, M. \& Szarowska, M., 2001. Molecular systematics of Hydrobiidae (Mollusca: Gastropoda: Rissooidea): testing monophyly and phylogenetic relationships. Proceedings of the Academy of Natural Sciences of Philadelphia, 151: 1-21. 